\title{
Characteristics and Stocks of Soil Nutrient under Various Land Use Types in a Super Wet Tropical Rain Forest Padang, West Sumatra
}

\author{
Hermansah ${ }^{1}$, Nofrita Sendi ${ }^{1}$, Yulnafatmawita ${ }^{1}$, Tsugiyuki Masunaga ${ }^{2}$ and \\ Toshiyuki Wakatsuki ${ }^{3}$
}

Received 12 February 2009 / accepted 4 December 2009

\begin{abstract}
Characteristics and Stocks of Soil Nutrient under Various Land Use Types in a Super Wet Tropical Rain Forest Padang, West Sumatra (Hermansah, N Sendi, Yulnafatmawita, T Masunaga and T Wakatsuki): In order to clarify the characteristics and stocks of soil nutrient under various land use types in a super wet tropical rain forest in Padang, West Sumatera, an investigation of the nutrient characteristics of the several samples of soils under different land use such as cacao plantation (CP), cinnamon plantation (CMP), mixed garden (MG), and primary forest (PF) in Gadut Mountain, Padang, West Sumatra was conducted. The soil nutrient characteristics varied among the different land use types. The range of nutrient characteristics under four land use type were $4.60-7.01 \%$ and $0.4-0.60 \%$ for total carbon and total nitrogen and were 9.80-24.59, $0.68-2.07$ and $0.30-0.8 \mathrm{cmol}(+) \mathrm{kg}^{-1}$ for $\mathrm{Ca}, \mathrm{Mg}$ and K, respectively. The highest content of soil nutrient status was found under MG, while the lowest soil nutrient status found at PF. This result indicated that the $\mathrm{MG}$ with various vegetation types might contribute in enriching the organic matter in soil. The soil nutrient content such as $\mathrm{TN}$, exchangeable $\mathrm{Ca}, \mathrm{Mg}$ and $\mathrm{K}$ tended to decrease with soil depth of each land use type. However, the sodium (Na) content in soil tended to increase within the soil depth. These were presumably due to evaporation of $\mathrm{Na}$ at surface soil within the study area was low. These study results showed that spatially the nutrient properties of soil were closely related to the land use type and management practices. It was suggested that the nutrient characteristics of soils under various land use types in a super wet tropical rain forest region, in Gadut Mountain, Padang West Sumatra were significantly affected by the land use types and land coverage.
\end{abstract}

Keywords: Land use, nutrient characteristics, super wet tropical rain forest, West Sumatra

\section{INTRODUCTION}

The study on the change of soil characteristics as a result of land use change is an essential matter in studying agroecosystem alteration and the persistence of land productivity. The important issue in studying the change of ecology function is determination of correct indicator that has high sensitivity toward ecosystem change that used to determine land quality. The characteristics and stocks of soil nutrient such as carbon, nitrogen and base cations are the indicators that used to monitor soil quality as there is a change in land cover and land clearance processes. Soil in wet tropical area is categorized as putrefied that has low fertility and has low input farming system. The fertility of this soil tremendously depends on the condition of organic matter from various vegetations that grow on the land.

Super wet tropical rain forest of West Sumatra that located in Gadut Mountain is a research field for forest ecology and soil study that under cooperation between Andalas University and some Japanese researchers which consolidated in Field Biology Research Project (FBRT) since 1984. This tropical forest area has a heavy rainfall that ever reached 5000 mm per year in 1986 (Wakasutki et al. 1986), has various vegetations and a dense and secured canopy. Some studies about characteristics and nutrient cycle in related to various types of vegetation and soil in natural super wet tropical rain forest ecosystem was

\footnotetext{
${ }^{1}$ Faculty of Agriculture, Andalas University, Limau Manis, Padang, Indonesia

${ }^{2}$ Faculty of Life and Environmental Science, Shimane University, Nishikawatsu-cho, Matsue 690-8504, Japan

${ }^{3}$ Faculty of Agriculture, Kinki University, Nakamachi 3327-204 Nara, Japan

J Trop Soils, Vol. 15, No. 1, 2010: 55-62

ISSN 0852-257X
} 
conducted previously by Masunaga et al. (1998), Kubota et al. (2000) and Hermansah et al. (2003).

In present day, actually the condition of this forest ecosystem almost change to other different land use such as cacao plantation, cinnamon plantation, mixed garden and even it just left with thicket after deforestation.

Study about characteristics and nutrient stocks as an indicator of land quality in observing the persistence of an ecosystem in Gadut Mountain that constitutes upstream area of Padang city is never conducted before. Therefore, the study on characteristics and nutrient stocks under various land use types in a super wet tropical rain forest of Gadut Mountain Padang, West Sumatra had been conducted. The objective of this research is to determine the characteristics and nutrient stocks under various land use types as an indicator of land quality change. This article is focused on the characteristics and nutrient stocks of total carbon (TC), total nitrogen (TN), and all base cations that provided in the soil.

\section{MATERIALS AND METHODS}

\section{Site Description}

This research is conducted in a foothills of Gadut Mountain, West Sumatra. This area is located in 460 $-550 \mathrm{~m}$ above the sea level (Figure 1). It is a new ecosystem that undergoes a change from primary forest becomes mixed garden, cacao plantation and cinnamon plantation. The annual rainfall of this area was more than 5,000 $\mathrm{mm}$ and there was no significant dry season found annually in this area (Hotta 1984; 1986; 1989). Wakasuki et al. (1986) stated that the soil of Gadut Mountain belong to Unmatured Dystropept and Europept, developed from limestone and andesite. However, according to the new soil classification that known as Soil Taxonomy (Soil Survey Staff 1999); it could be classified as Dystroudepts and Eutroudepts. Because the research field is located in Gadut Mountain foothills, thus materials such as stones that come from the hilltop are easy to find in this area. Land activities and clearance process in mixed garden is longer than cacao plantation and cinnamon plantation. Mixed garden is overgrown with durian, mangosteen, nutmeg, coffee, and banana.

\section{Sampling Method}

In order to determine the characteristics and stocks of soil nutrient under various land use types, then the soil samples are collected from several land use such as cacao plantation (CP), cinnamon (CMP), mixed garden (MG) and from primary forest (PF) as comparator or control. Horizontally monitoring the variation of characteristics and soil nutrient stocks, then the samples is collected in five points of observation for each land use types. And to monitor the soil characteristics vertically, then the samples is collected in deepness $(0-5 \mathrm{~cm}, 5-20 \mathrm{~cm}$ and $20-40$ $\mathrm{cm})$ until it is found hard core by using the auger. Thereby, the range of samples in each point of observation is varied; depend on the effective depth of each drilling location.

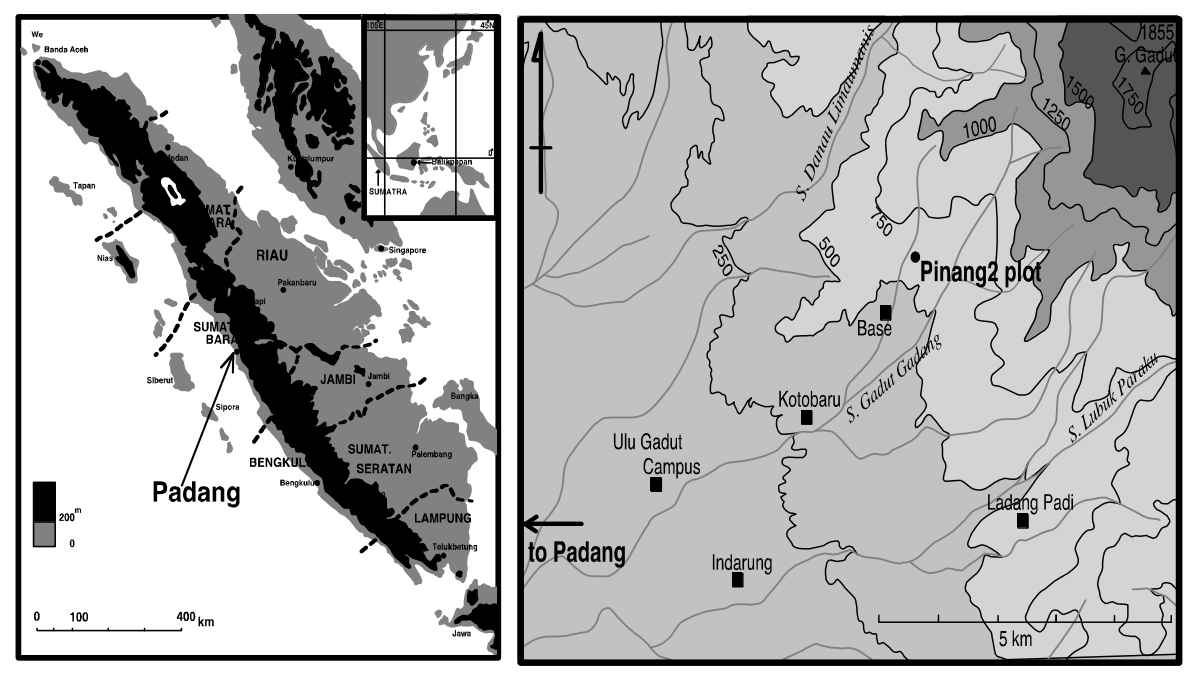

Figure 1. Map showing a research site at Gadut area, Padang, West Sumatra. 


\section{Laboratory Methods and Data Analyses}

Soil samples that have been dried is refined and sifted by using $2 \mathrm{~mm}$ sieve. Soil reaction is measured by using electrode glass with soil and water ratio 1 : 2.5 (IITA 1979; Mc Lean 1982). Base cations (Ca, $\mathrm{Mg}, \mathrm{K}$, and $\mathrm{Na}$ ) are extracted with $1 \mathrm{~m} \mathrm{~L}^{-1}$ ammonium acetate $\mathrm{pH}$ 7.0 (Thomas 1982), and measured by using Atomic Absorption Spectrophotometer (Shimadzu, AS 680). Effective cations exchange capacity is measured by counting up the value of base cations and acid cations.

\section{RESULTS AND DISCUSSION}

\section{The Land Uses Dynamics}

The research field is located in Koto Baru area, Sub district of Pauh that located around $25 \mathrm{~km}$ east part of Padang City. Geographically it is placed in coordinate $100^{\circ} 29^{\circ} 40^{\prime \prime}$ and $100^{\circ} 30^{\prime} 40^{\prime \prime}$ east and between $0^{\circ} 54^{\prime} 55^{\prime \prime}$ and $0^{\circ} 55^{\prime} 45^{\prime \prime}$ south. The research field is a part of Gadut Mountain area that recognized as one of super wet tropical rain forest area in Indonesia and even in the world, with rainfall intensity more than $6,000 \mathrm{~mm}$ per year. Thereby, this area is categorized as a super wet tropical rain forest area (Richards 1996). Annual average temperature of this location is $27^{\circ} \mathrm{C}$ with low fluctuation between maximum and minimum temperature $\left(<2^{\circ} \mathrm{C}\right)$. The rain season in this area is found in November and April, while the dry season is almost never found in this area during the year. Monthly humidity of this area is ranged from 13 and $80 \%$ with annual average in $77 \%$. Based on Kopen's season classifications, this area is categorized as Afa-Ama, and included in Zone A based on Oldeman classification (Ogino 1994). Thus, the forest reservation and the ecosystem of this area have to be safeguarded in order to keep the function and the role of this area as water control and as disaster control such as flood and slide.

However, in reality a large measure of the land in this area have been clearances, estimated starting since 50 years ago. People around the research field have been planted the land with annual plant such as tree. The dominant plant that grown by the people is mangosteen (Garcinia magostan L.), durian (Durio zibetinus), cinnamon (Cinnamon burmanii) and cacao (Theobroma cacao L.), beside those plants, it is also grown with banana (Musa sp.). The land processing activity in the low slope of Pinang - Pinang hill always increase, it is well marked by the same planting process.

\section{Soil Nutrient Characteristics}

Based on the field survey and soil analysis in laboratory, it is found that the soil in the research field is categorized as early developed soil and classified as Inseptisol order. This finding is approved with the condition where the soil solum is narrow, with effective depth less than $40 \mathrm{~cm}$. Through the soil solum; it has a high hardcore percentage, it is estimated around $86 \%$ in $10-20 \mathrm{~cm}$ depth.

The soil texture in the middle slope of a foot hill of the research field is categorized as silty clay loam and in the low slope of the foot hill is silty loam and silty (Yulnafatmawita et al. 2007). The soil permeability is immediately classified in each of land use types.

Soil $\mathrm{pH}$, total organic $\mathrm{C}$, total $\mathrm{N}$ and base cations under the four land use types in the research field are presented in Table 1.

Soil reactions under four land use types range from acid and slightly acid. Acid reaction is found under primary forest while the other land use types, mixed garden, cacao plantation, and cinnamon plantation have low acid reaction. Land use alteration to non forest such as mixed garden, cacao plantation, and cinnamon plantation do not show a reduction on organic matter, in another hand it tends to increase the organic matter on mixed garden compared to primary forest.

The total soil organic carbon in $0-10 \mathrm{~cm}$ depth in each of land use types are $7.01 \%, 5.73 \%$ and $4.80 \%$ for mixed garden, cinnamon plantation, and cacao plantation, respectively. Total organic carbon tends to decrease following the soil depth of each land use types (Table 1). Organic matter in the land that used as mixed garden with main vegetation includes durian, mangosteen, banana and grasses such as bulrush that grow quickly in the land. The high content of organic $\mathrm{C}$ in mixed garden is carried by organic sources that return in the form of remnant of undergrowth clearing process such as grasses and underbrush that grow in interstice of mature plants that could be done ones or twice a year. The remnant of the clearing process just left to be putrefied and some of them are pilled up in some of the spots and then burned up. The quickly growth of the grasses is initiated by the high intensity of the rainfall and enough illumination system. But, how much nutrient was contributed by remnant of 


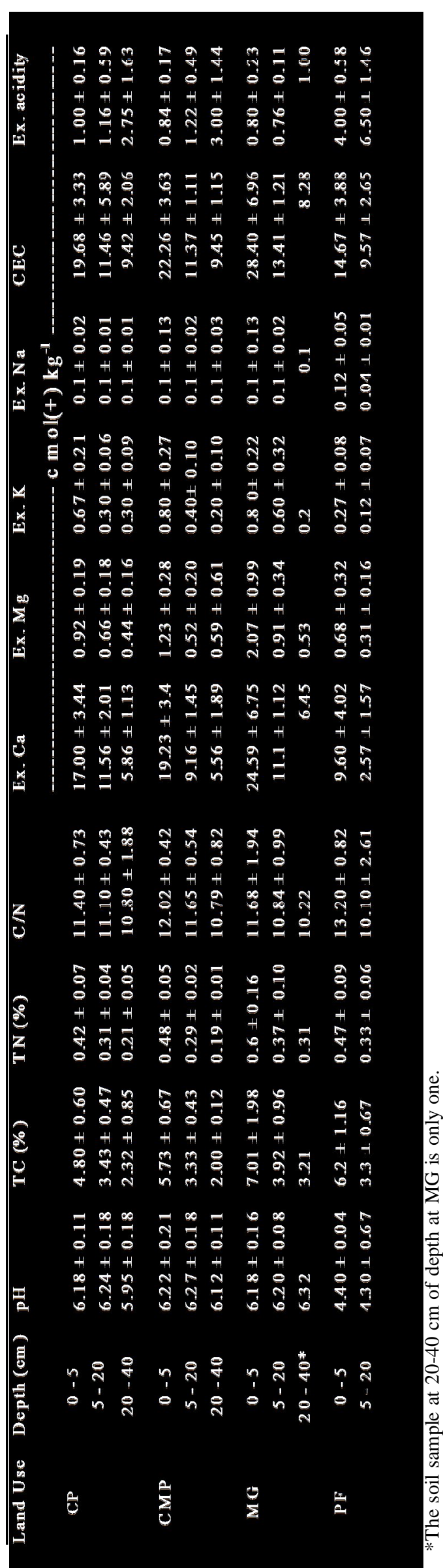

clearing process articulately was not discovered yet. A quantitative analysis for this case is also needed.

Total C content under each of land use types decrease with soil depth. It shows an indication that soil organic matter is always accumulated in top soil. It happens because almost organic sources constitute to the result of litterfall of the vegetation that grow in the top soil. From the previous research (Hermansah et al. 2003) it was found that the total litterfall of primary forest in Pinang - Pinang area was $11.8 \mathrm{Mg}$ per hectare per year. This value is higher than litterfall value of tropical forest in Brazil (Luizão 1989).

Total $\mathrm{N}$ in mixed garden tends to be higher than cinnamon plantation, primary forest and cacao plantation (Table 1). The higher level of total $\mathrm{N}$ in mixed garden was presumably due to the higher level of organic matter that left by remnant of grasses from the clearing process and litterfall of the vegetations in the mixed garden. Just as organic C content, total $\mathrm{N}$ under each of land types is decreased following the soil depth.

Base cations such as $\mathrm{Ca}$ are categorized as high and very high criteria. The highest $\mathrm{Ca}$ is $24.50 \mathrm{cmol}$ (+) $\mathrm{kg}^{-1}$ of soil; it is found under mixed garden and followed by cinnamon plantation and cacao plantation. And the lowest $\mathrm{Ca}$ is found under primary forest. But, if it is compared with assessment criteria of land fertility status (Pusat Penelitian Tanah 1983), the $\mathrm{Ca}$ content in this forest ecosystem could be categorized as very high in comparison with Ca status in another tropical rain forest such as in Malaysia (Burghouts 1993). Ca content of the research field is higher. It is assumed that it happens because the main material of the soil is dominated by commixture between andesite material and lime stone.

$\mathrm{Mg}$ content tends to show a same pattern with $\mathrm{Ca}$, land use with mixed garden pattern has a high $\mathrm{Mg}$ level, while the lowest $\mathrm{Mg}$ level is found under primary forest. $\mathrm{K}$ content for mixed garden and cinnamon plantation is the same. $\mathrm{K}$ content in primary forest is also in low level. The low content of the base cations $(\mathrm{Ca}, \mathrm{Mg})$ in primary forest is parallel with the high level of soil acidity in that area.

The distribution patterns of nutrient characteristics based on soil depth under each land use types could be seen in Figure 2. Figure 2a until 2d, it could be seen that the soil nutrient is decreased following the soil depth. Each of land use shows a different distribution pattern. 
From figure 2 it could be suggested that vertically the nutrient content ( $\mathrm{TN}, \mathrm{Ca}$ and $\mathrm{Mg}$ ) is decreased following the soil deepness in each of land use types. The soil fertility variations in the top soil $(0-5 \mathrm{~cm})$ also varied in each of land use types. Land use for mixed garden shows a high variability level of soil fertility in $\mathrm{N}, \mathrm{Ca}$, and $\mathrm{Mg}$. It indicates that accumulation of organic matters in a land which are the main source of soil nutrient is varied to one another. Besides, it also might be caused by the restitution process of organic matters are not conducted with the same system. The farmers do this process by their own ways.

Total carbon (\%)

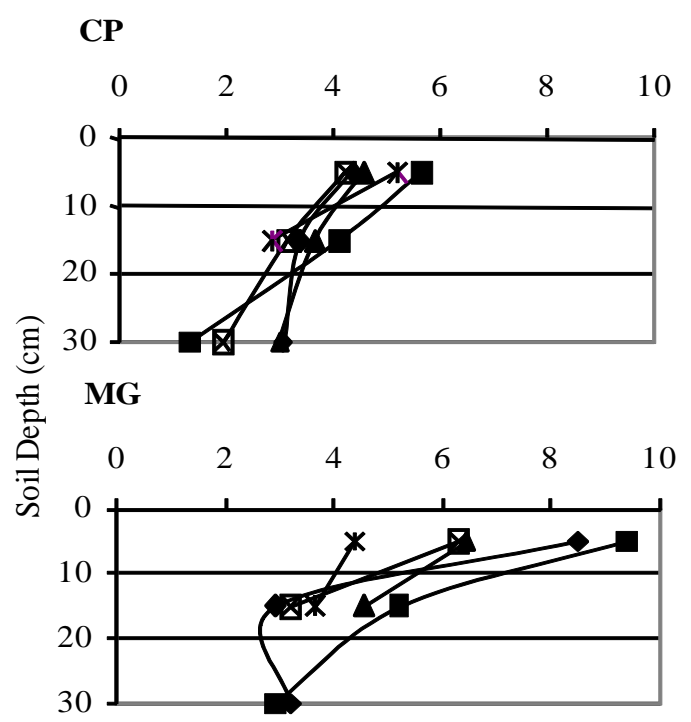

CMP
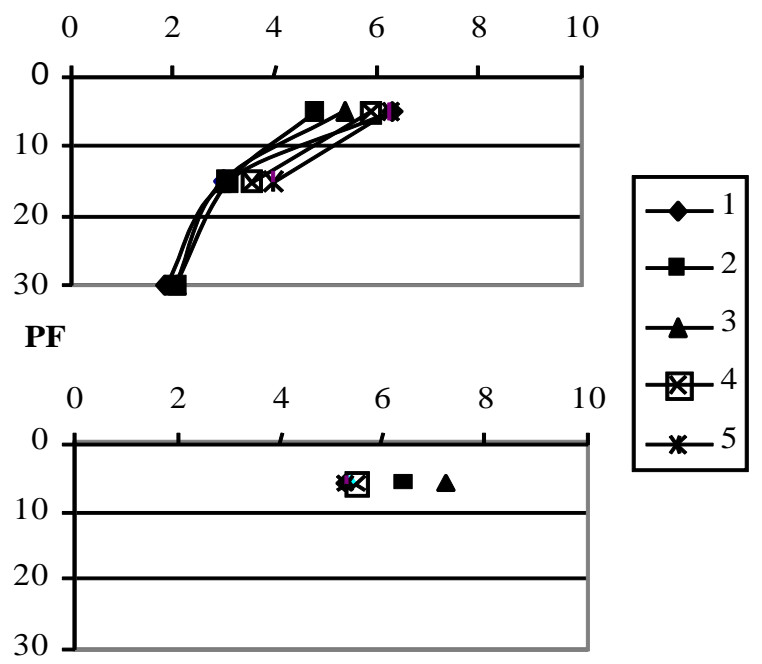

Figure 2a. Distribution of total carbon (\%) with the soil depth at four land use types. $\mathrm{CP}=$ cacao plantation, $\mathrm{CMP}=$ cinnamon plantation, $\mathrm{MG}=$ mixed garden, and $\mathrm{PF}=$ primary forest; $1,2,3,4$, and 5 are the sampling point of each land use types.

Total nitrogen $(\%)$

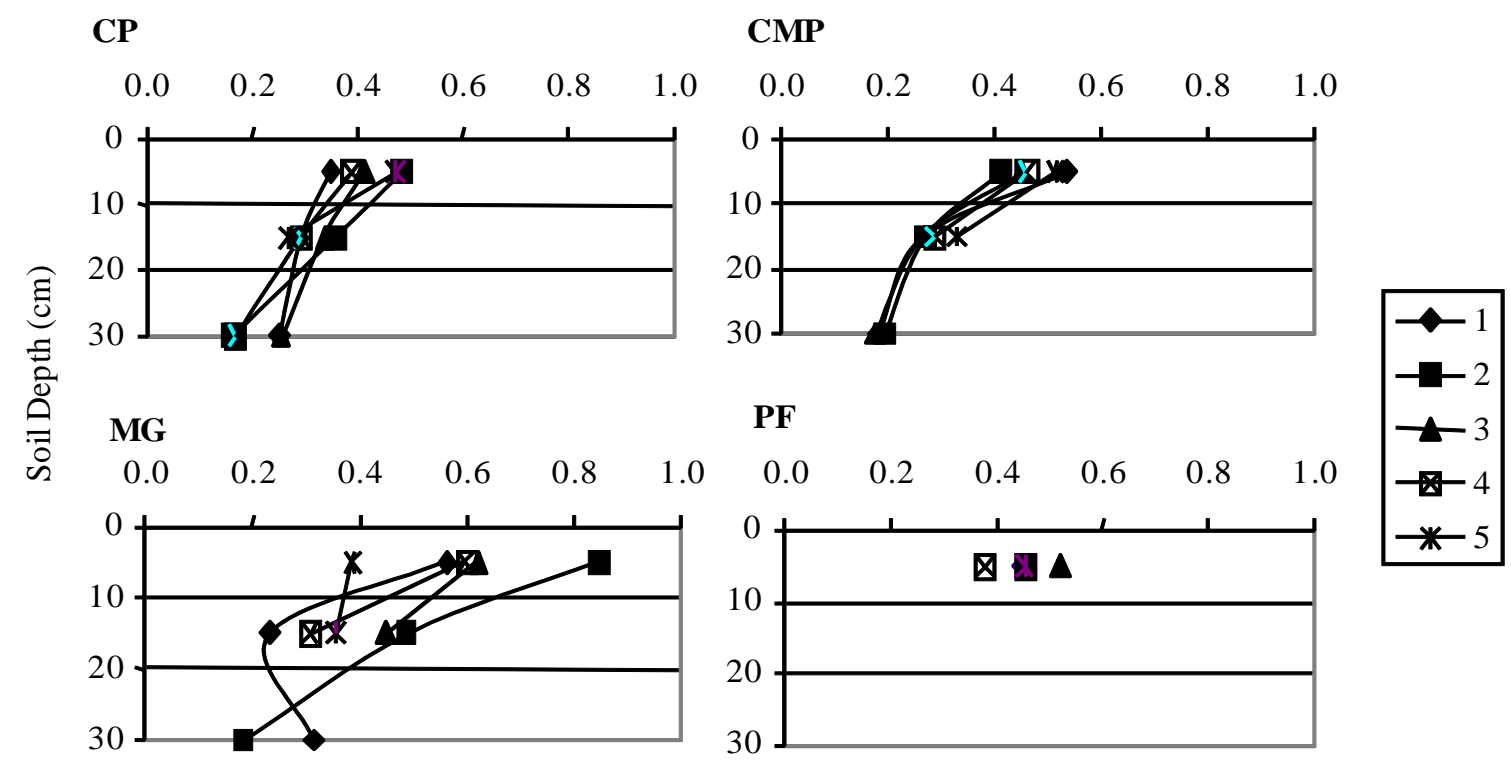

Figure $2 \mathrm{~b}$. Distribution of total nitrogen $(\%)$ with the soil depth at four land use types. $\mathrm{CP}=$ cacao plantation, $\mathrm{CMP}=$ cinnamon plantation, $\mathrm{MG}=$ mixed garden, and $\mathrm{PF}=$ primary forest; $1,2,3,4$, and 5 are the sampling point of each land use types. 


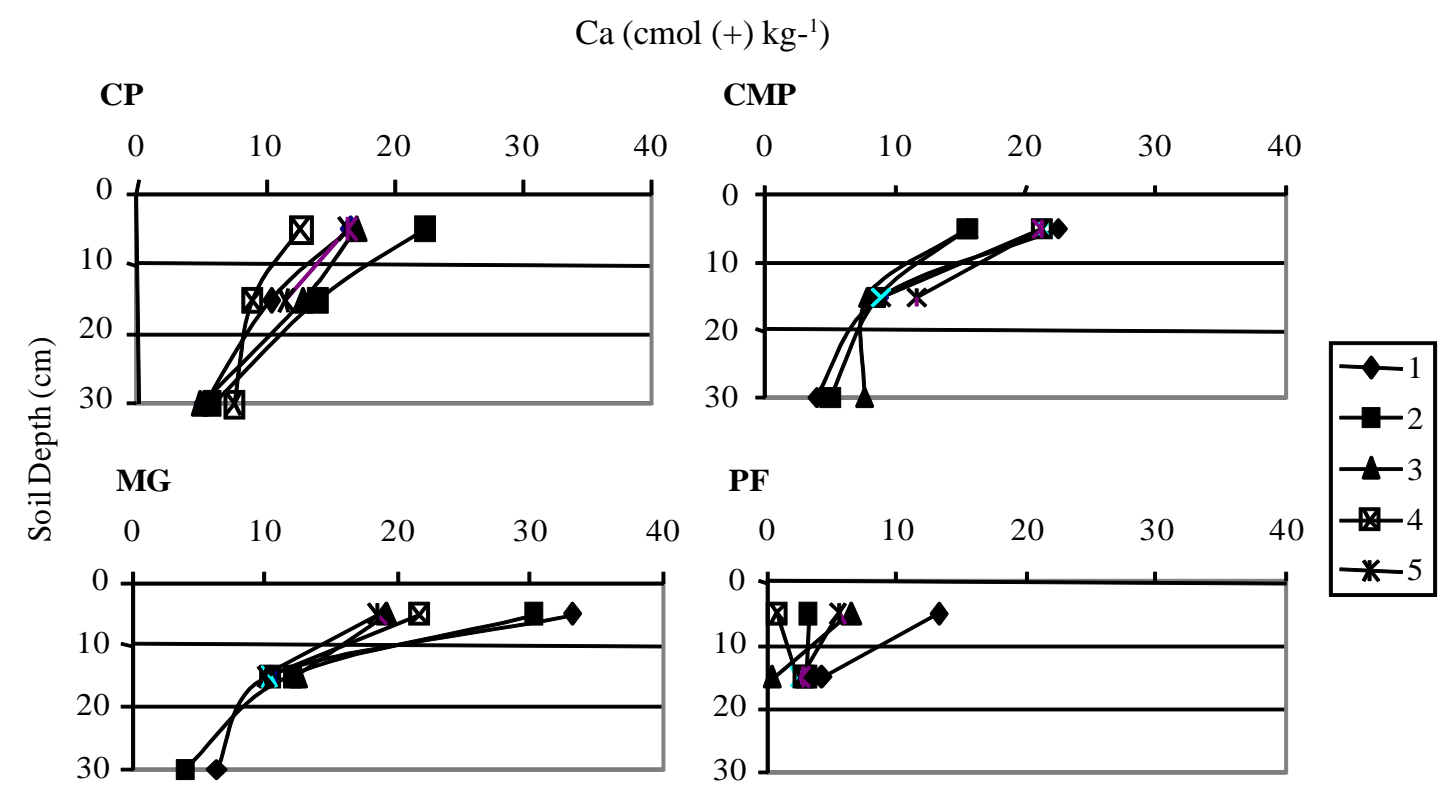

Figure 2c. Distribution of exchangeable Ca $\left(\mathrm{cmol}(+) \mathrm{kg}^{-1}\right)$ within the soil depth at four land use types. $\mathrm{CP}=$ cacao plantation, $\mathrm{CMP}=$ cinnamon plantation, $\mathrm{MG}=$ mixed garden, and $\mathrm{PF}=$ primary forest; $1,2,3,4$, and 5 are the sampling point of each land use types.

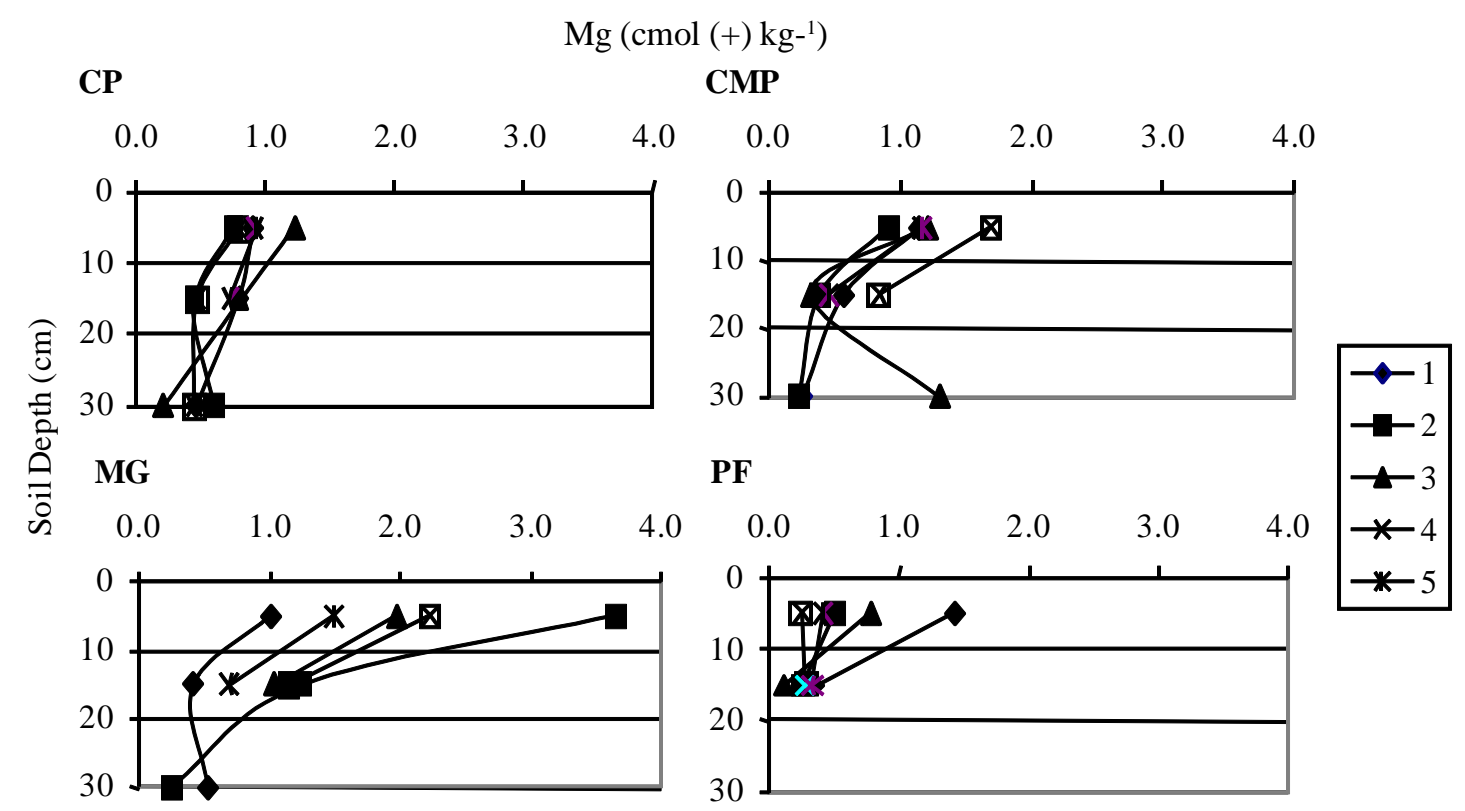

Figure 2d. Distribution of exchangeable $\mathrm{Mg}\left(\mathrm{cmol}(+) \mathrm{kg}^{-1}\right)$ within soil depth at four land use types. $\mathrm{CP}=$ cacao plantation, $\mathrm{CMP}=$ cinnamon plantation, $\mathrm{MG}=$ mixed garden, and $\mathrm{PF}=$ primary forest; $1,2,3,4$, and 5 are the sampling point of each land use types.

\section{Soil Nutrient Stocks}

The distribution of soil nutrient stocks (TN, Ca, $\mathrm{Mg}, \mathrm{K}$ and $\mathrm{Na}$ ) in $0-5,5-20$ and $20-40 \mathrm{~cm}$ deepness under all four land use types in super wet tropical rain forest Padang is presented in Figure 3.
Nutrient stocks of $\mathrm{N}$ in the deepness $0-5 \mathrm{~cm}$ is found at 2,104, 2,381, 3,017 and 2,350 kg per hectare for cacao plantation, cinnamon plantation, mixed garden and primary forest. From the data above, it could be seen that mixed garden has highest nutrient stocks of 


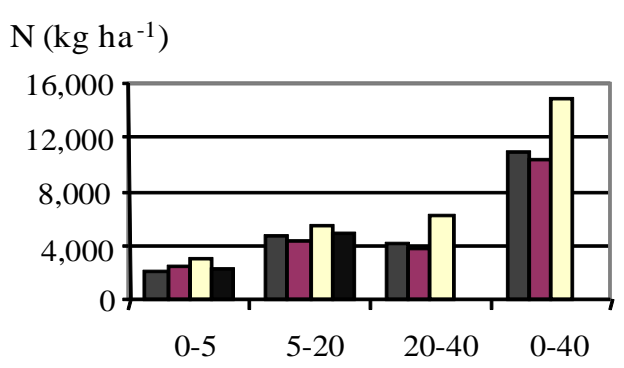

$\mathrm{Ca}\left(\mathrm{kg} \mathrm{ha}^{-1}\right)$
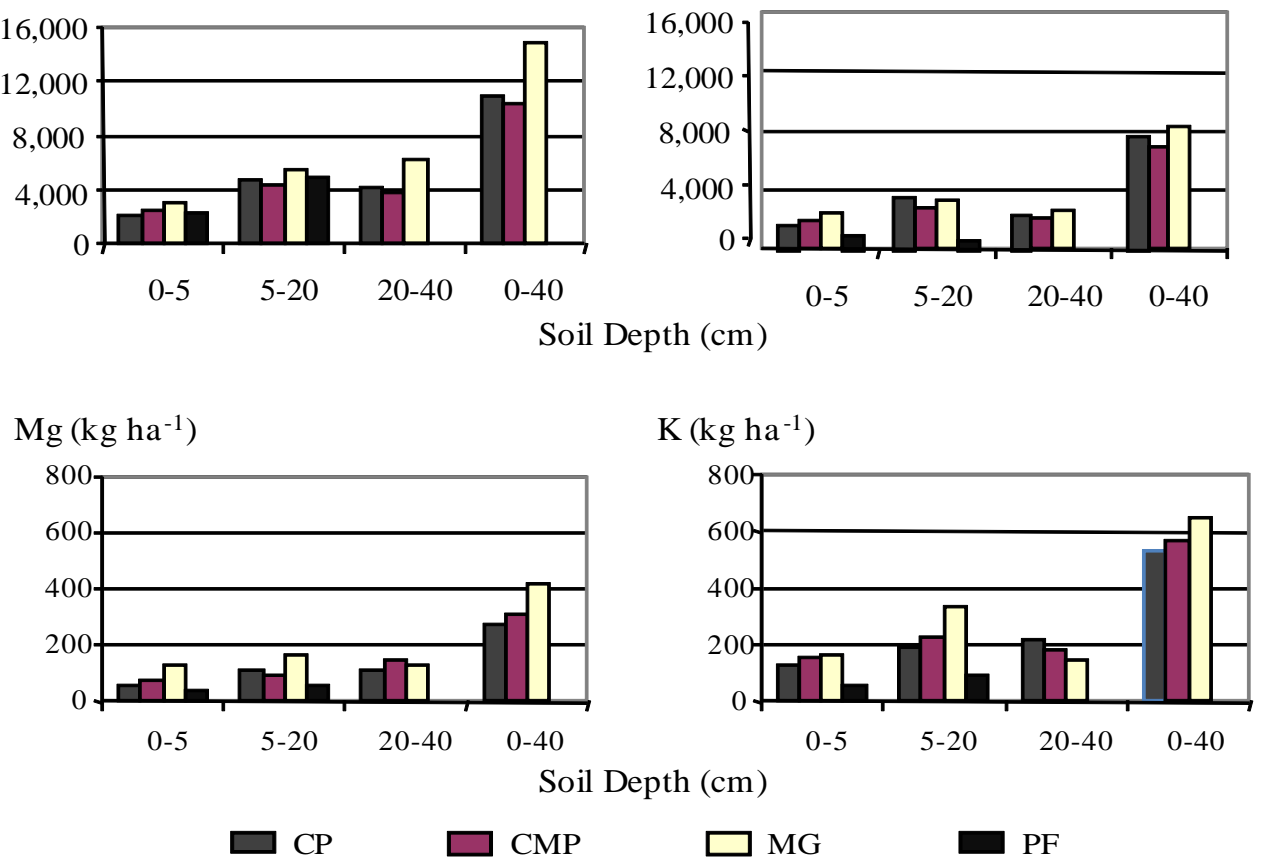

Figure 3. Soil nutrient stocks under various land use types in a super wet tropical rain forest Gadut, Padang. $\mathrm{CP}=$ cacao plantation, $\mathrm{CMP}=$ cinnamon plantation, $\mathrm{MG}=$ mixed garden, and $\mathrm{PF}=$ primary forest.

$\mathrm{N}$ in the deepness $0-5 \mathrm{~cm}$ than the other land use types. It indicates that land use in mixed garden could give a nutrient inside the soil through accumulated of organic matters that was produced. The source of organic matters in mixed garden not only comes from litterfall of natural vegetation but also from remnant of grasses that left while clearing process was done by the farmers. Stock of $\mathrm{N}$ contain in the deepness $0-20$ is higher than in $20-40 \mathrm{~cm}$.

Likewise, $\mathrm{Ca}$ a stock at $0-20 \mathrm{~cm}$ depth is also higher than $\mathrm{Ca}$ stocks under $20-40 \mathrm{~cm}$ depth. It verifies that the accumulated of soil nutrient such as $\mathrm{Ca}$ in tropical rain forest that used for mixed garden is found in top soil $(0-20 \mathrm{~cm})$. Total Ca in $0-20$ of soil depth is almost $70 \%$ from total Ca contain in 0 $40 \mathrm{~cm}$. Nutrient stocks of $\mathrm{Mg}$ and $\mathrm{K}$ is also found to be high in mixed garden, $60 \%$ stocks of $\mathrm{Mg}$ and $\mathrm{K}$ in $0-40 \mathrm{~cm}$ depth is found in top soil. But, if it compares with nutrient stocks of $\mathrm{Na}$, it will be found that percentage of Na content in top soil is lowest than the sub soil (20 - 40). It might be caused by a very low of $\mathrm{Na}$ evaporation process in this area which is a super wet tropical rain forest. It was very contradicted with the result in the dry place that I found in Singkarak, Solok, and West Sumatera (Hermansah et al. 2006) where the Na content is tended to be higher in top soil than in the sub soil.

\section{CONCLUSIONS}

The land use change to be mixed garden with agroforestry pattern give a contribution toward soil fertility by increasing soil organic matter and it has the best characteristics and nutrient stocks than the other land use types.

\section{ACKNOWLEDGMENT}

We dedicate our great gratitude and special honor to DP2M DGHE of the Republic of Indonesia that has donated this research and give me an opportunity to conduct a bequest fundamental research on 2008 . My great thanks also goes to JASSO who give an opportunity to stay and doing some analyses of soil in Shimane University Japan.

\section{REFERENCES}

Burghouts TBA. 1993. Spatial Variability of Nutrient Cycling in Bornean Rain Forest. Ph.D. Thesis, Vrije Universiteit, Amsterdam, 156 pp. 
Hermansah Z, Aflizar, T Masunaga and T Wakatsuki. 2003 Micro spatial distribution pattern of litterfall and nutrient flux in relation to soil chemical properties in a Super Wet tropical rain forest, West Sumatra, Indonesia. Tropics 12 (2): 131-146.

Hermansah Z, Aflizar, T Masunaga and T Wakatsuki. 2003. Dynamics of litter production and its quality in relation to climatic factors in a Super Wet tropical rain forest, West Sumatra, Indonesia. Tropics 12 (2): 115-130.

Hermansah, S Syintalina, T Masunaga and T Wakatsuki. 2006. Soil Nutrient Dynamics in different Land Use Along the Toposequence of Singkarak region in West Sumatra, Indonesia. In: Proceeding the $18^{\text {th }}$ World Congress of Soil Science, Pennsylvania, USA. 9 15 July 2006.

Hotta M. 1984. Forest ecology and Flora of Gunung Gadut, West Sumatra. Sumatra Nature Study (Botany), Kyoto University, Kyoto, 220 p.

Hotta M. 1986. Diversity and Dynamics of Plant Life in Sumatra, Part 2. Sumatra Nature Study (Botany) Kyoto University, Kyoto, 128 p.

Hotta M. 1989. Diversity and Plant Animal Interaction in Equatorial Rain Forest, Sumatra Nature Study (Botany) Kagoshima University, Kagoshima, 302 p.

IITA. 1979. Selected Methods for Soils and Plant Analysis, Manual Series No. I, IITA, Ibadan.

Kubota D, T Masunaga, Hermansah, M Hotta, Y Shinmura and T Wakatsuki. 2000. Soil quality characterization in relation to tree species diversity in tropical rain forest, West Sumatra Indonesia I. Comparison of two 1-ha plots. Tropics 9 (2): 133-145.

LuizãoF, PMatson, GLivingston, RLuizão and PVitousek. 1989. Nitrous oxide flux following tropical land clearing. Global Biogeochem Cyc 3: 281-285.
Masunaga T, D Kubota, M Hotta and T Wakatsuki. 1998. Nutritional characteristics of mineral elements in leaves tree species in tropical rain forest, West Sumatra, Indonesia. Soil Sci Plant Nutr 44 (3): 315329.

McLean EOP. 1982. Soils pH and Lime Requirement. In: AL Page, RH Miller and DR Keeney (eds). Methods of Soil Analysis Part $22^{\text {nd }}$ ed Agron Monogr 9. ASA and SSSA, Madison, Wis, pp. 199-209.

Ogino K, M Hotta, T Rusjdi and T Yoneda. 1984. Forest Ecology of G. Gadut area. In: M Hotta (ed), Forest Ecology and Flora of G. Gadut. Sumatra Nature Study (Botanya). Kyoto University, Kyoto, pp. 15-27.

Pusat Penelitian Tanah. 1983. Jenis tanah dan macam tanah di Indonesia untuk keperluan survey dan pemetaan tanah daerah transmigrasi. Bogor. (In Indonesian).

Richards PW. 1996. Tropical rain forest climates and their distribution. In: The tropical rainforest $\left(2^{\text {nd }} \mathrm{ed}.\right)$, Cambridge University Press, Cambridge, pp. 159-171.

Soil Survey Staff. 1999. Key to Soil Taxonomy. $8^{\text {th }}$. Ed Ed USDA Natural Resources Conservation Service Washinton DC.

Thomas GW. 1982. Exchangeable cations. In: AL Page, RH Miller and DR Keeney (Eds). Methods of Soil Analysis Part $22^{\text {nd }}$ ed Agron Monogr 9. ASA and SSSA, Madison, Wis, pp. 149-157.

Wakatsuki, T., A. Saidi, and A. Rasyidin. 1986. Soils of the toposequences of the G. Gadut tropical rain forest, West Sumatra, Southern Asian Studies. Soil Sci Plant Nutr 24: 243-265.

Yulnafatmawita, Asmar, M Haryanti and S. Betrianigrum. 2007. Pengukuran bahan organik tanah bukit PinangPinang kawasan hutan hujan yropik G. Gadut Padang. J Soil Land Util Manag VI (2): 54-65. (In Indonesian). 